УДК 792:7.072.3(410)Кол](045)

ORCID: https://orcid.org/0000-0001-9266-5672

Тернова Марина Володимирівна, кандидат філософських наук, доцент кафедри суспільних наук. Київський національний університет театру, кіно i телебачення імені І. К. Карпенка-Карого, Київ

Maryna Ternova,

(PhD Philosophy science) Associate Professor of the Department of social sciences in Kyiv National I. K. Karpenko-Karyi Theatre, Cinema and Television University, Kyiv

\title{
ТЕАТР У ВИДОВІЙ СТРУКТУРІ МИСТЕЦТВА: ДОСВІД Р. Дж. КОЛЛІНГВУДА
}

Анотація. На підгрунті теоретичної спадщини відомого англійського філософа, історика науки, естетика та мистецтвознавця Р. Дж. Коллінгвуда у статті виокремлено низку питань пов'язаних з історією та теорією європейського театру, витоки якого сягають доби Античності. Водночас, до аналізу грецького театру долучений магічно-релігійний чинник, якому у мистецтвознавчій концепції Р. Дж. Коллінгвуда надається особлива роль, оскільки його значення вкрай важливе не лише для становлення театру, а й для мистецтва загалом.

Наголошено зацікавлене ставлення англійського науковця до видової структури мистецтва в цілому та його конкретних видів зокрема. У поле зору Р. Дж. Коллінгвуда потрапили і живопис, і музика, і кінематограф, проте осмислення театру відбувалося найбільш фундаментально на засадах історикомистецького підходу.

Ключові слова. Види мистецтва, театр, актор, магічно-релігійні витоки «театрального дійства», грецько-елліністична театральна практика, «стрит-арт», типи театрів, «груповий театр».

Постановка проблеми та актуальність дослідження. Мистецтвознавчі ідеї Р. Дж. Коллінгвуда (1889-1943), які формувалися на початку ХХ століття й були втілені в багатоаспектній монографії «Принципи мистецтва» (1938), можуть стати предметною основою для грунтовного аналізу низки важливих проблем. Серед них і проблема видової специфіки мистецтва загалом, і театру зокрема. При цьому, мається на увазі як історичний аспект розвитку театру, так і тенденції його естетико-художньої спрямованості в умовах перших десятиліть ХX століття. Річ у тім, що Р. Дж. Коллінгвуд був сучасником тих доленосних для європейської культури процесів, якими позначилася передусім межа XIX-XX ст., зокрема, символізм та авангардизм, вплив яких на розвиток театральної культури не можна недооцінювати.

Сфокусувавши увагу на проблемах європейського театру, включаючи у цей контекст і того- часний англійський театральний простір, слід зазначити, що символізм вніс принципові зміни у напрацьовані традиції й існування актора на сцені та психології сприйняття символістської драматургії. Новації символістів поглибилися експериментами авангардистів, адже своєю увагою театр не оминали ані дадаїсти, ані абстракціоністи, ані сюрреалісти, закладаючи підгрунтя для експериментів «театру абсурду», що найвиразніше окреслилися впродовж 50-70-х рр. ХХ століття.

«Театрознавча позиція» Р. Дж. Коллінгвуда, представлена на сторінках «Принципів мистецтва», дає змогу створити своєрідний «пластичний міст» не лише між різними історико-культурними етапами у розвитку театру, а й концептуалізувати сучасне розуміння природи і сутності одного з найдавніших видів мистецтва. На нашу думку, все означене актуалізує теоретичну спрямованість даної статті.

Аналіз сучасних досліджень і публікацій. Широке коло проблем історії театру, його стану 
в умовах перших десятиліть XXI століття, достатньо широко представлені в сучасній українській гуманістиці. Приділяючи увагу традиціям національного театру (М. Вороний, Н. Корнієнко, Г. Веселовська, М. Гринишина, О. Демідко, А. Лягущенко, С. Павличко, О. Фіалко) українські театрознавці, культурологи та естетики одночасно чітко окреслюють теоретичні проблеми, що пов'язані із розвитком європейської театральної культури (Н. Владимирова, Ж. Дедусенко, В. Корнієнко, Г. Миленька, Є. Миропольська). Водночас низка публікацій торкається подекуди суперечливих питань функціонування чи то структурних елементів вистави, чи то морально-психологічних ситуацій, що виникають всередині театральної трупи (Т. Батицька, О. Водяніна, Л. Ковальчук, Л. Овчієва, Б. Сюта). Спираючись на наявні напрацювання, авторка статті зосереджує увагу на театрознавчій моделі Р. Дж. Коллінгвуда, яка варта більш предметного використання в процесі реконструкції історико-культурних етапів розвитку європейського театру. Окрім театрознавчих джерел, у статті використані естетико-культурологічні наукові розвідки, які дають можливість реконструювати творчо-пошукове підгрунтя, на якому «будувалася» модель Р. Дж. Коллінгвуда.

Mema cmammi. Проаналізувати театрознавчі ідеї Р. Дж. Коллінгвуда в контексті обгрунтованої ним загальної концепції видової структури мистецтва, що дає підстави актуалізувати феномен «спадкоємності» в логіці руху історико-культурних етапів від давньогрецького до «групового» театру Руперта Дуна.

Виклад основного матеріалу. Серед естетикомистецтвознавчих проблем, які мають місце в європейській гуманістиці від часів Античності, проблема видів мистецтва посідає помітне місце. Наразі, слід враховувати, що тогочасний грецький театр розвивався як паралельно з іншими видами мистецтва (література, жанри поезії та драматургії, архітектура, скульптура, танець), так і в органічному зв'язку з естетико-мистецтвознавчою теорією. Відштовхуючись від цього, слід особливо виокремити історико-теоретичний підхід, на який спирається Р. Дж. Коллінгвуд, фокусуючи увагу на театрі як принципово важливому виді мистецтва, активно включеному у культуротворчі процеси, що «супроводжують» людину на різних етапах іiі історії.

Реконструюючи театрознавчі ідеї Р. Дж. Коллінгвуда, слід враховувати і те значення, яке він надавав магії, первісним релігійним віруванням людини, що, на його думку, відіграли наріжну роль у виникненні мистецтва. Показово, що вже у «Вступі» до «Принципів мистецтва» учений зазначає: «Грецька драма і грецька скульптура зародилися як приналежності релігійного культу» (Коллингвуд, 1999, с. 22).

Зафіксувавши магічно-релігійні витоки театру, адже поза «грецькою драмою» театральна вистава неможлива, Р. Дж. Коллінгвуд і надалі залишається впевненим щодо обрисів релігійності у театральному «дійстві». Витоки театрального мистецтва, які він визначив, збігаються з позиціями інших дослідників, котрі першими «виставами» грецького театру вважають підготовку і проведення свят на честь бога Діоніса. Вони традиційно проводилися тричі на рік і, відповідно до цього, у Греції певний час зберігалася практика щорічних трьох вистав. Оскільки розквіт театру збігається з так званим «періодом демократичних Афін», найширші прошарки грецького населення мали змогу відвідувати театральні вистави.

Наступна теза, що багато значить в позиції англійського дослідника, пов'язана 3 аналізом філософсько-естетичних ідей Платона, зокрема, 3 широко розповсюдженою на європейських наукових теренах інтерпретацією конкретних текстів філософа i, зокрема, тих, де він начебто гостро негативно поставився до поетів та не зробив їх громадянами «ідеальної держави». Принагідно слід наголосити, що Р. Дж. Коллінгвуд, якого вважають визнаним фахівцем з історії науки, активно відстоював необхідність нових перекладів праць давньогрецьких філософів, передусім, діалогів Платона, вважаючи, що у старих варіантах має місце досить приблизне трактування використаних ним не лише слів, а й коротких речень (Коллингвуд, 1999, с. 51).

На думку Р. Дж. Коллінгвуда, адекватний переклад платонівських розмислів дає змогу стверджувати, що він «мав намір допустити в своїй державі якийсь-то тип драми, що своїм характером нагадує скоріше за все драми Есхіла». Проте такий підхід Платона до драми як підгрунтя театральної вистави поступово змінюється, а його погляди стають більш жорсткими: «Уся драматургія має зникнути, і він залишається лише з тою поезією, головним представником якої був Піндар» (Коллингвуд, 1999, с. 56).

Деяка іронічність, що простежується в оцінці Р. Дж. Коллінгвудом вибору Платона, на нашу думку, досить надмірна, оскільки Піндар (522/518448/438) - один 3 дев'яти найвизначніших ліричних поетів Античності, який викликав повагу і відверте захоплення. Окрім цього, його цінували як знавця і зберігача грецьких міфів, а специфіка творчості Піндара була пов'язана з колективним 
хоровим виконанням його «поезій», оскільки вони, у своїй переважній більшості, були звернені до богів, закладаючи, водночас, найдавнішу манеру «оповідального» типу творчості. «Поезії» Піндара не лише уславлювали богів, а й засобами хорового співу «оповідали» про перемоги в битвах, про життя героїв, про велике кохання (Пиндар, https://dicacademic.ru>dic.Nsf>ruwiki).

У контексті означеного, цілком вірогідним $є$ припущення, що, захоплюючись творчістю Піндаpa, зокрема використанням хору, Платон навряд чи був проти колективного виду творчості, до якого належать і хор, і театр. Водночас, античний філософ не приховував і свого негативного, у деяких випадках, ставлення до театру, одну з причин якого, на думку Р. Дж. Коллінгвуда, слід шукати у феномені «розважальності», що почала виявлятися у грецькому культурному просторі ще за життя Платона.

Слід визнати, що певна іронічність Р. Дж. Коллінгвуда стосовно платонівського захоплення поезією Піндара, аж ніяк не стосується оцінки ним інших теоретичних «проривів» мислителя, якому англійський дослідник дає титул «пророка». Р. Дж. Коллінгвуд поділяє точку зору Платона, яка «базується на живому відчутті реальності: він бачить різницю між старим і новим мистецтвом, різницю між олімпійськими фронтонами і Праксителем, намагаючись іiї проаналізувати» (Коллингвуд, 1999, c. 60).

У процитованому фрагменті 3 «Принципів мистецтва» ключовим слід вважати слово «різниця», проте його аналіз, за твердженням Р. Дж. Коллінгвуда, недосконалий і обриси «різниці» виявляються на тлі «нового мистецтва», що його Платон розглядає як «мистецтво занадто збудженого й незмірно емоційного світу» (Коллингвуд, 1999, с. 60). Однак, як вважає англійський теоретик, у своїх оцінках Платон помилився: на зміну великому грецькому мистецтву йшла не «збудженість» чи «незмірна емоційність», а «спустошеність»: «Платон, на порозі занепаду Греції, як пророк дивиться у сумне і моторошне майбутне, кидаючи усю енергію свого героїчного розуму на відвернення катастрофи. Аристотель, громадянин вже нового, елліністичного, світу, не бачить в ньому нічого загрозливого. Але загроза існує» (Коллингвуд, 1999, c. 60$)$.

Позицію Р. Дж. Коллінгвуда щодо розмислів Платона доцільно розглядати і як символічний теоретичний вирок Греції, що виявилася неспроможною зберегти власну культуру, і як накреслення шляху до елліністичного театру, що, у новій культурній площині не міг наслідувати грецькі театральні традиції.

Елліністичний театр, який представлений Р. Дж. Коллінгвудом дещо строкато, потребує певної уваги, передусім тому, що формує своєрідну «зону переходу» від Античності до Середньовіччя та Відродження - періодів, коли цей вид мистецтва набуває нових рис. Трансформація грецького театру в елліністичний зумовлювалася, насамперед, політичною ситуацією, оскільки Афіни, програвши пелопоннеську війну, втратили вплив над територією усієї Греції і сприяли піднесенню Македонії.

Історія елліністичного театру асоціюється 3 життям Олександра Македонського, за роки царювання якого театру приділялася значна увага: у великих містах будувалися нові приміщення для проведення вистав, підтримувалася практика створення «синоду техніків»- перших об'єднань працівників театру, з'явилося нове амплуа «міма»-актора, який виступав або самостійно, або супроводжував виставу. Саме елліністичний театр досить вдало використав термін «мімос»- наслідування, копіювання, вклавши в обов' язки «міма» наслідувати чи копіювати якісь побутові процеси, створюючи на сцені «замальовки» максимально наближені до реального життя.

Однак найбільше важить той факт, що у просторі театру принципово змінилася творча орієнтація, реалізувалося саме те, проти чого пристрасно виступав Платон: елліністичний театр став «розважальним» видом мистецтва, зосередившись на розробці жанру комедії при максимальному використанні творів Менандра (342-292 до н.е.). Як відомо, у першій половині XX століття археологами були знайдені рукописи його творів, що дало можливість відновити тексти таких п'єс, як «Полюбовний суд» та «Відлюдник».

У проєкції часу стало очевидно, що Менандр свідомо «опонував» творам Аристофана, який започаткував жанр «політичної комедії». На відміну від свого видатного попередника, підгрунтям комедій Менандра виступали побутові та сімейні ситуації, гранично наближені до реального життя, а своїм своєрідним гаслом Менандр обрав «правдоподібність».

Не лише театральна культура, яка потребує персоналізованого підходу, а й узагальнені досягнення Античності залишалися тогочасними надбаннями і впродовж тривалого історичного періоду не трансформувалися в європейський культурний простір. Тож у добу Середньовіччя театру довелося розпочинати свою історію, по суті, з чистого аркуша. 
На нашу думку, реконструюючи ставлення Р. Дж. Коллінгвуда до середньовічного театру, слід звернути увагу на той факт, що він не намагався навіть ескізно відтворити умови, в яких європейський театр існував упродовж V-XV століть, коли Кіпріан та Тертулліан, одні з перших ідеологів християнства, не лише заборонили театр, а й проголосили його єрессю і всіх, хто був дотичний до театрального мистецтва, відлучали від християнських общин. Попри це, на європейських теренах зберіглися мандрівні трупи, які подорожували країнами, виступаючи переважно на ярмарках і спеціалізуючись на виконанні невеличких сатиричних фарсів. Поступово діячі церкви збагнули емоційний потенціал «театрального дійства», використовуючи акторів для виконання «літургійних драм», що слід оцінювати як поштовх до становлення «світського» театру, який «будувався» на міщанських (бюргерських) п’єсах.

Сьогодні увагу привертає наукова розвідка українського культуролога М. Чікарькової «Середньовічні витоки стріт-арту» (2020), в якій акцентовано увагу на, так би мовити, експериментах середньовічних мандрівних театрів, де «вуличні артисти - ваганти, мінезингери, жонглери, шпільмани, барди, скальди, менестрелі, скоморохи тощо, мандрували з одного міста до іншого, й ці гастролі сприяли культурному єднанню краю» (Чікарькова, 2020, с. 102). Зокрема, дослідниця наголошує на різних зрізах людських здібностей, оскільки «в цих гастролях поєднувалися поетичний хист і музична обдарованість, драматичний талант виконавця ролі й, часом, фізичний розвиток акробата» (Чікарькова, 2020, с. 102).

У статті М. Чікарькової $є$ показове посилання на розвідку S. Androna «Selling streetness as experience. The role of street art tours in branding the creative city» (2018), на сторінках якої здійснено порівняльний аналіз середньовічного «стріт-арту» і творчих пошуків сучасних акторів, музикантів, дизайнерів, котрі вважають вулиці та будинки простором для експериментів. У такому контексті на перший план висуваються прихильники «перформансів» та «графіті» (Andron, 2018).

Як історик науки, якому добре відома і середньовічна культура і організаційно-художні підвалини тогочасного театру, Р. Дж. Коллінгвуд надає перевагу концептуалізації матеріалу, а не лише його описанню. Унаочнити загальні проблеми європейської культури Р. Дж. Коллінгвуд зміг на теренах середньовічного театру, який, за його твердженням, повернувся до магічно-релігійних витоків.

Принагідно наголосимо, що на тлі проблем середньовічного мистецтва, торкаючись його різних видів, науковець знову і знову прагне наголосити значення магічної форми стимулювання почуттєвої природи людини. 3 цього приводу Р. Дж. Коллінгвуд зазначає: «Якщо магічне мистецтво досягає високого естетичного рівня, це відбувається тому, що суспільство, до якого воно належить (і не тільки художники, але й глядачі), вимагає від мистецтва естетичної досконалості, яка далеко перевищує той скромний ступінь кваліфікації, що дозволила б реалізувати усі його магічні функції» (Коллингвуд, 1999, с. 75).

Задля всебічної аргументації наріжної ідеї своєї концепції, Р. Дж. Коллінгвуд залучає відоме дослідження Зігмунда Фрейда (1856-1939) «Тотем і табу», наголошуючи, що з усього тексту він зміг скористатися лише третім розділом. Адже концепція магічно-релігійних і ритуальних засад мистецтва, яку відстоював 3. Фрейд, виявилася для Р. Дж. Коллінгвуда неприйнятною, оскільки засновник психоаналізу пов'язував інтерес до магічно-релігійного та ритуального феноменів 3 виявами «душевної хвороби», 3 комплексом «варвара», який не дотичний до європейської цивілізації. Натомість Р. Дж. Коллінгвуд зауважує, що людина, яка «здатна звести історичну проблему природи цивілізацій до проблеми медичної, - це людина, погляди якої на всі проблеми, пов'язані 3 природою цивілізації, будуть тим більш помилковими, чим чесніше вона зберігатиме вірність цій своїй спробі» (Коллингвуд, 1999, с. 82).

Слід акцентувати, що як магічно-релігійне мистецтво взагалі, так і роль ритуального чинника у формуванні театру зокрема, у різних частинах монографії «Принципи мистецтва» стають предметом прискіпливої уваги Р. Дж. Коллінгвуда. Значення магічно-релігійного чи ритуального чинників традиційно постає в дослідженнях фахівців первісної культури, «розчиняючись», водночас, і в розвідках іншого спрямування. Щодо Коллінгвуда - він, вочевидь, прагне «не загубити» ці чинники, хоч які б проблеми ним порушувалися. Справляється враження, що вони мають для науковця особистісне значення і стають його «улюбленою темою». Оскільки подібна тенденція простежується і в працях інших науковців, ми вважали за необхідне особливо артикулювати факт відвертого акцентування Коллінгвудом ідеї магічно-релігійних і ритуальних витоків мистецтва.

На нашу думку, для англійського дослідника, який надзвичайно високо цінував добу Відродження, було цілком логічним торкнутися і тих нових тенденцій, що простежуються у ренесансному театрі. Наразі, розгляду його «театрознавчої позиції» має передувати реконструкція поняття «мистецтво», яку він здійснив. Зокрема, Р. Дж. Коллінгвуд 
зазначає: «Ars у середньовічній латині, так само як і Art у так званій ранній новоанглійській мові, повністю запозичені як і це слово і його зміст, що означає будь-яку форму спеціальної книжкової освіти, такої як граматика, логіка, магія чи астрономія» (Коллингвуд, 1999, с. 18). Наразі Р. Дж. Коллінгвуд нагадує читачам монографії «Принципи мистецтва» вислів одного з героїв Шекспіра: «Залишся тут, моє мистецтво!»-говорить Просперо, знімаючи свою чарівну мантію» (Коллингвуд, 1999, с. 18).

За часів Відродження, вважає Р. Дж. Коллінгвуд, ситуація почала змінюватися, оскільки до слів «Ars-Art» повернулося їх попереднє значення - ремесло. Митці Відродження, «подібно до своїх побратимів з Давнього світу, насправді вважали себе ремісниками» (Коллингвуд, 1999, с. 18) Принагідно зазначимо, що саме представники італійської ренесансної моделі паралельно з ремісником називали себе «майстрами», терміном, який значно пізніше трансформувався у поняття «митець». Відтак Р. Дж. Коллінгвуд вважає доречним нагадати, що лише у XVII столітті «проблеми і концепції естетики почали виокремлюватися з проблем техніки або філософії ремесла».

Означена тенденція набула особливих рис упродовж XVIII століття, коли «розподіл зайшов так далеко, що виникла різниця між витонченими мистецтвами і корисними мистецтвами». Свій стислий аналіз історико-культурних процесів у гуманістиці Нового часу Р. Дж. Коллінгвуд завершує дещо суперечливою тезою: «Тепер (тобто наприкінці XVIII століття - М.T.) «витончені» мистецтва означали не просто витонченість або високий професіоналізм ремесла, а «прекрасні» мистецтва...». Деталізуючи свою думку, він додає: «У XIX столітті це словосполучення було скорочено, епітет відпав і заміна множинного числа одиничним додала узагальнюючого смислу слову мистещтво» (Коллингвуд, 1999, с. 18). На нашу думку, річ не в тому, що десь загубився епітет «прекрасне», а в тому, що в умовах Відродження стало чітко зрозумілим, що «прекрасне» не мистецтво, а те, що заслуговує на оцінку «прекрасне», відтак дискусійність Коллінгвудової тези сьогодні очевидна.

У даний контекст, який завдяки розмислам Р. Дж. Коллінгвуда, висвітлює певні теоретичні труднощі й суперечності, що «супроводжували» ренесансну гуманістику, чітко «вписуються» проблеми тогочасного театру. Так, по-перше, теоретик кваліфікує його як «народний» та «розважальний», а по-друге - не дистанціює від низки більш розлогих проблем, у контексті яких «театр» виявляється лише конкретним сегментом. Навіть враховуючи нормативи статті, ми все ж повинні наголосити, що ці суперечливі питання потребують хоча б стислого коментування.

Оскільки Р. Дж. Коллінгвуд негативно поставився до «розважального» мистецтва, то такий аспект ренесансного театру ним не підтримувався. Натомість теоретик позитивно оцінив його «народність»: «У ренесансному театрі співробітництво між автором і акторами, з одного боку, і глядачами - 3 іншого, було живою реальністю» (Коллингвуд, 1999, с. 292). Це переконання стимулює його розмірковування щодо глядачів, які становлять «театральну аудиторію». Зокрема, науковець переконаний, що «народний» театр формують не стільки автор п'єси чи актори, скільки зацікавленість глядачів подіями, що розгортаються на сцені, їхні емоції й, так би мовити, оціночна реакція.

Такі, дещо загальні, розмисли Р. Дж. Коллінгвуда набували особливої ваги в період «антиаристотелізму», який переживало Відродження. Йдеться про засади «традиційної логіки», що «полягають у певному методі, який був вперше систематично викладений (наскільки можна довіряти текстам, що дійшли до нас) в «Органоні» Аристотеля» (Коллингвуд, 1999, с. 237). Цей підхід, як зазначає Р. Дж. Коллінгвуд, дістав подальшого розвитку і активно підтримувався середньовічними логіками. Пізніше, метод на якому «будувалася» традиційна логіка Аристотеля, був знехтуваний як такий, демонструючи «безплідні, химерні розміркування». Подібна інтерпретація традиційної (аристотелевської) логіки панувала як у філософії італійського Ренесансу, так і протягом усього XVII століття.

Як зазначає Р. Дж. Коллінгвуд, пізніше до аристотелевського «методу» почали повертатися, проте робили це «з численними застереженнями», що обумовлювалося як анти-аристотелевським рухом, так і новим «прочитанням» самого Аристотеля: «...це було зроблено, так званими ідеалістами XVIII і XIX століття від Канта до Бредлі і далі, та відтворений з незначними змінами сучасними фахівцями з логічного аналізу та позитивістами» (Коллингвуд, 1999, с. 237).

Наша прискіплива увага до трансформацій «методу» саме в контексті «народного» ренесансного театру спричинена наріжною ідеєю аристотелевського «методу, мета якого полягає в тому, аби «перетворити мову на бездоганний засіб вираження думки» (Коллингвуд, 1999, с. 237). Театру можливо більше ніж будь-якому виду мистецтва потрібна мова, що здатна донести думку: «народний» ренесансний театр, значною мірою завдяки настановам Аристотеля зміг це зробити. 
Яскравим підтвердженням справедливості основних засад, на які спирався Коллінгвудів аналіз «ренесансного» театру, є творчість відомого італійського драматурга та лібретиста Карло Гольдоні (1707-1793), професійне становлення котрого тісно пов'язане з Венецією. Скорившись волі батька, Гольдоні став юристом і навіть певний час працював помічником судді та адвокатом, що дозволило йому краще зрозуміти життя італійців, їхне, 3 одного боку, реальне існування, а з іншого, надії та сподівання. Зрештою, мріючи про театр від студентських років у єзуїтській колегії в Перуджі, він написав низку трагедій, які, хоча і були представлені публіці, проте не мали успіху.

Познайомившись 3 комедією Макіавеллі «Мандрагора», творами Мольєра та англійською літературою межі XVII-XVIII століття, Гольдоні почав усвідомлювати обмеженість сценічної практики «Commedia dell ’arte» - театру, що на початку XVIII століття зберігав «маски», використовуючи ïх у прямому чи опосередкованому значенні, та експлуатував принцип імпровізації. Гольдоні виступає опонентом такого театру і починає дуже обережне, але все ж послідовне його реформування. Поступово в італійському культурному простоpi, як відомо, формуються дві театральні течії: «венеційські» комедії Карло Гольдоні та «Commedia dell arte» Карло Гоцці (1720-1806) - засновника жанру «фьябі» - театральної казки «Корольолень», «Турандот», «Принцеса Китаю» мали і мають до сьогодні великий успіх.

Не приймаючи естетико-художніх засад театру Гоцці, а відтак, прагнучи осягнути нові аспекти жанру комедії, Гольдоні фактично одразу здобув значний успіх п’єсами «Слуга двох господарів» (1746), «Кав’ярня» (1750) та «Брехун» (1751).

Визнання цих творів, надихнуло Гольдоні i до написання нових комедій («Трактирниця», 1753), і на обгрунтування власної творчої позиції, підгрунтям якої стала ідея комедії як великого людського ярмарку, де зустрічаються люди різних соціальних прошарків та характерів (Гольдоні, https://www.livelib.ru>author>125202-karlo-Goldoni). Принагідно підкреслимо, що чим популярнішою ставала творчість Гольдоні, тим гостріше його критикував Гоцці, котрий наполягав на «витонченій», «фантазійній» комедії, не визнаючи iї «побутовонародної» спрямованості. Під тиском критики, Гольдоні, автор 267 комедій, змушений був емігрувати до Франції де жив і працював протягом 30 років.

Реконструювавши «за» і «проти» ренесансного театру, Р. Дж. Коллінгвуд, віддавши належне Шекспіру, намагається окреслити стан англійсько- го театру на початку і протягом трьох десятиліть $\mathrm{XX}$ століття. Як відомо, в означений період і драматургія, і акторська майстерність тогочасного театру були досить високими, вирізняючись багатоаспектністю театрального репертуару.

Як відомо, за часів Р. Дж. Коллінгвуда, в Англії існували «комерційні» та «репертуарні» театри. При цьому вважалося, що саме друга група виступає джерелом творчих відкриттів. Це було вкрай важливим для розвитку цього виду мистецтва, оскільки так звана репертуарна політика була доволі чітко регламентована: 1. Добре написана п'єса. 2. Салонна драма. 3. Поетична драма. Проте, означені аспекти не цікавлять Р. Дж. Коллінгвуда і він зосереджує увагу на потенціалі п'єси, яка зазнає численних інтерпретацій, на значенні репетицій у процесі створення вистави, на прийомах, що застосовують задля встановлення зв'язків між сценою та глядацьким залом. Окрім цього, у «Принципах мистецтва» 3'являються розмисли щодо ролі костюму, який має відіграти досить помітну роль.

Слід визнати, що тенденція до деталізації тих аспектів складових, які визначають успіх театральної вистави, зберігається і в сучасному театрознавстві. Підтвердженням цього $є$ наукові розвідки Н. Бугай «Людина як субститут абсолюту: синкретична стадія формотворення в костюмі» (2010) та О. Водяпіної «Театральний костюм в системі сценічного простору та часу як комунікативний феномен» (2010). Авторка останньої розглядає театральний костюм як «комунікант, презентатив вищих цінностей, це та межа, дія, жест, подія, яка здійснює можливість виходу за межі реальності, існування в просторі співбуттєвих адеквацій реальності...» (Водяпіна, 2010, с. 307). Ставлення до театру як виду мистецтва із складною структурою, що продемонстрував як Р. Дж. Коллінгвуд, так і інші тогочасні театрознавці, закріпилося в європейському мистецтвознавстві, спонукаючи сучасних науковців, творчо, а не механічно, розширювати театрознавчо-мистецтвознавчі межі, вводячи п’єсу, сценографію, декорації, костюм, реквізит вистави в контекст культурологічного аналізу. Це переконливо демонструє органічний зв'язок «культурологія - мистецтвознавство», на теренах якого працюють такі українські культурологи, як Л. Бабушка, Т. Кохан, Т. Кривошея, О. Маланчук-Рибак, О. Петрова, С. Холодинська.

В умовах сучасної гуманістики стає зрозумілим, що окремі теоретичні напрацювання Р. Дж. Коллінгвуда $є$ предтечою культурологічного підходу, адже у 30-ті роки, коли він готував монографію «Принципи мистецтва» до видання, в англомовному 
середовищі було відоме і поняття «культурологія», і перші напрацювання американця Леслі Алвіна Уайта (1900-1975), котрий власне і ввів у теоретичний ужиток поняття «культурологія». Це, певною мірою, $\epsilon$ аргументом щодо правомочності оперування терміном «персоналізація» стосовно матеріалу, який Р. Дж. Коллінгвуд присвятив Бернарду Шоу (1856-1950) та Руперту Дуну (1903-1966).

П'єси видатного ірландського драматурга Б. Шоу, котрий атрибутується сьогодні і як політичний діяч, Р. Дж. Коллінгвуд відверто не сприймав, стверджуючи, що «слід було б звільнитися від сценічних вказівок у дусі Бернарда Шоу» (Коллінгвуд, 1999, с. 296). Це невтішне зауваження він до того ж пояснив у більш ніж розгорнутому вигляді:

Коли бачиш п’єсу обплутану й перенасичену подібними надмірностями, залишається лише протерти очі і запитати: «Що це? Може бути автор сам вважає себе таким поганим письменником, що йому не під силу роз'яснити власні наміри режисеру і трупі без допомоги коментарів, які нагадують шкільне видання? Або режисери і актори в ті часи, коли створювалися ці кумедні архаїчні фрагменти, були такими ідіотами, що не могли поставити п'єсу поза цих неймовірно багатослівних настанов? (Коллингвуд, 1999, с. 296-297).

Окрім означеного, Р. Дж. Коллінгвуд чітко відносить творчість Б. Шоу до «розважального» мистецтва, яке він, як вже підкреслювалося, послідовно засуджував. Наразі англійський теоретик $є$ вкрай тенденційним, оскільки такі п’єси ірландського драматурга як «Професія місіс Уорен», «Зброя і людина», «Кандід», «Пігмаліон», «Поживемо - побачимо» та низка інших, за які Б. Шоу здобуває Нобелівську премію з літератури (1925), оцінюються визнаними фахівцями як реальне надбання європейської культури першої половини XX століття.

Більш поблажливим Р. Дж. Коллінгвуд виявився до Р. Дуна - танцюриста, хореографа, театрального режисера, педагога, організатора «Групового театру», котрий дав обіцянку своїм глядачам, що вони на кожній виставі будуть іï активними учасниками (Дун, https://hrwiki.ru>wiki>Rupert Doone).

Як ми зазначали, Р. Дж. Коллінгвуд неодноразово наполягав на тому, аби глядач не був пасивною стороною «театрального дійства», а режисери та актори мали навчитися «динамізувати» глядацький зал. Водночас, Коллінгвуд добре розумів, що одна справа теорія, а зовсім інша практика, і цілком слушно констатував: «...складним питанням буде те, як цей принцип провести у життя» (Коллингвуд, 1999, с. 298).
Висновки. Підсумовуючи матеріал викладений у статті, слід визнати доцільність історикокультурного підходу, що застосував Р. Дж. Коллінгвуд, репрезентуючи театр серед інших видів мистецтва. Відштовхуючись від магічнорелігійних та ритуальних засад, які відіграли потужну роль у формування театру, він реконструював різні типи театральної культури, успішно використовуючи потенціал порівняльного аналізу.

Чітке уявлення щодо «театрознавчих ідей» Р. Дж. Коллінгвуда дають його персоналізовані оцінки творчості драматургів, режисерів та акторів, котрі забезпечили успіх англійського театру у першій половині XX століття.

\section{Джерела та література}

Водяпіна, О. В. (2010). Театральний костюм в системі сценічного простору та часу як комунікативний феномен. Актуальні філософські та культурологічні проблеми сучасності, 25. С. 305-312.

Гольдони Карло [ЕР]. Режим доступу: https:/www.livelib.ru/ author/125202-karlo-goldoni

Дун Pуперm [ЕР]. Режим доступу: https://www.buildwiki.ru/ wiki/Rupert_Doone

Коллингвуд, Р. Дж. (1999). Принцииьь искусства. Москва: Языки русской культуры.

Пиндар [ЕР]. Режим доступу: https:/dic.academic.ru/dic.nsf/ ruwiki/777

Чікарькова, М. Ю. (2020). Середньовічні витоки стріт-арту. Вісник Маріупольського державного університету. Серія: філософія, культурологія, соціологія, 19. С. 99-106.

Andron, S. (2018). Selling streetness as experience: The role of street art tours in branding the creative city. The Sociological Review, 66 (5). Pp. 1036-1057.

\section{References:}

Andron, S. (2018). Selling streetness as experience: The role of street art tours in branding the creative city. The Sociological Review, 66 (5). Pp. 1036-1057. [in English]

Chikarkova, M. Yu. (2020). Serednovichni vytoky strit-artu [Medieval origins of the street art]. Visnyk Mariupolskoho derzhavnoho universytetu. Seriia: filosofiia, kulturolohiia, sotsiolohiia [Bulletin of Mariupol State University. Series: Philosophy, culture studies, sociology], 19. Pp. 99-106. [in Ukrainian]

Collingwood, R. G. (1999). Printsipy iskusstva [The Principles of Art]. Moskva: Yazyki russkoy kultury. [in Russian]

Doone Rupert. Retrieved from https://www.buildwiki.ru/wiki/ Rupert_Doone [in Russian]

Goldoni Carlo. Retrieved from https://www.livelib.ru/ author/125202-karlo-goldoni [in Russian]

Pindar. Retrieved from https://dic.academic.ru/dic.nsf/ ruwiki/777 [in Russian]

Vodiapina, O. V. (2010). Teatralnyi kostium v systemi stsenichnoho prostoru ta chasu yak komunikatyvnyi fenomen [Theatrical costume in the system of stage space and time as a communicative phenomenon]. Aktualni filosofski ta kulturolohichni problemy suchasnosti [Actual philosophical and culturological problems of the present], 25. Pp. 305-312. [in Ukrainian] 


\section{Maryna Ternova}

\section{Theater in the specific structure of art: experience R. J. Collingwood}

Abstract. Based on the theoretical heritage of the famous English philosopher, historian of science and aesthetics and art critic R.J. Collingwood, the article highlights a number of issues related to the history and theory of European theatre, which dates back to Antiquity. At the same time, the analysis of Greek theatre includes a magical-religious factor, which is given a special role in the art concept of Collingwood, as its importance is extremely significant not only for the formation of theatre, but also of art in general.

The English scientist's concern in the species composition of art in general and its specific types in particular has been emphasized. Painting, music, and cinematography fell under the spotlight of R.J. Collingwood, but his comprehension of theatre took place most fundamentally on the basis of a historical and artistic approach.

Key words. Types of art, theatre, actor, magical-religious origins of «theatrical action», Greek-Hellenistic theatrical practice, «street art», types of theatres, «the Group Theatre». 